\title{
PERANAN YAYASAN SWASTA TERHADAP PEMBERDAYAAN PETANI DESA DI DESA NGLANGGERAN, KECAMATAN PATUK, KABUPATEN GUNUNGKIDUL, DAERAH ISTIMEWA YOGYAKARTA
}

\author{
The Role of Private Foundations for Empowering Village Farmers in Nglanggeran \\ Village, Patuk Sub-district, Gunungkidul District, Special Region of Yogyakarta
}

\section{Jose Amadeus Krisna Foe*, Lasmono Tri Sunaryanto}

\author{
Program Studi Agribisnis, Fakultas Pertanian dan Bisnis, Universitas Kristen Satya Wacana, Salatiga \\ *Kontak penulis: 522016006@student.uksw.edu
}

\begin{abstract}
The empowerment of village farmers by the private sector and the government has a significant difference. Three factors influence the impact of empowerment on improving the welfare of farmers, namely the quality of empowerment facilities, the intensity of empowerment facility provision, and the quality of empowerment facilitators. Nglanggeran Village farmers receive empowerment facilities from the regional government in the form of plant seeds, fertilizer, livestock germs, pens, and training once a year. This is only enough for one growing season and is often late. When empowered by the Obor Tani Foundation, farmers receive facilities in a package called the Farmers Empowerment Center. The facilities are in the form of ponds, farmhouses, agricultural production facilities, training on 11 pillars of agricultural cultivation, and farmer cadres to guide farmers for 3.5 years. When empowered by the government, farmers only produce for individual food needs and do not fix the main agricultural problems in the village. When empowered by the Obor Tani Foundation, farmers' incomes have risen as well as the main agricultural problem in the village which is lack of water can be solved. Farmer empowerment strategies undertaken by the Obor Tani Foundation can be used as learning by the government to improve the quality of farmer empowerment.
\end{abstract}

Keywords: Farmer empowerment, Regional government, Non-government foundation.

\begin{abstract}
Abstrak
Pemberdayaan petani desa oleh swasta dan pemerintah memiliki perbedaan yang signifikan. Terdapat tiga faktor yang mempengaruhi dampak pemberdayaan terhadap peningkatan kesejahteraan petani yakni kualitas fasilitas pemberdayaan, intensitas pemberian fasilitas pemberdayaan, dan kualitas fasilitator pemberdayaan. Petani Desa Nglanggeran menerima fasilitas pemberdayaan dari pemerintah daerah berupa benih tanaman, pupuk, bibit ternak, kandang dan pelatihan setahun sekali. Ini hanya cukup untuk satu musim tanam dan sering terlambat. Pada saat diberdayakan oleh Yayasan Obor Tani, petani menerima fasilitas dalam satu paket yang disebut Sentra Pemberdayaan Tani. Fasilitas tersebut berupa embung, wisma tani, sarana produksi pertanian, pelatihan tentang 11 pilar budidaya pertanian, serta kader tani untuk membimbing petani selama 3,5 tahun. Pada saat diberdayakan oleh pemerintah, petani hanya memproduksi untuk kebutuhan pangan individual, serta tidak memperbaiki permasalahan pertanian utama di Desa tersebut. Saat diberdayakan oleh Yayasan Obor Tani, penghasilan petani meningkat serta permasalahan utama pertanian di Desa tersebut yakni kekurangan air dapat terselesaikan. Strategi pemberdayaan petani yang dilakukan oleh Yayasan Obor Tani dapat dijadikan pembelajaran oleh pemerintah untuk memperbaiki kualitas pemberdayaan petani.
\end{abstract}


Keywords: Pemberdayaan Petani; Pemerintah Daerah; Yayasan Swasta.

Sitasi: Foe, J. A. K, L. T. Sunaryanto, 2020. Peranan Yayasan Swasta Terhadap Pemberdayaan Petani Desa Di Desa Nglanggeran, Kecamatan Patuk, Kabupaten Gunung Kidul, Daerah Istimewa Yogyakarta, JSEP 16(2): 185 - 198.

\section{Pendahuluan}

Indonesia merupakan salah satu Negara di dunia yang mempunyai sumber daya alam melimpah, mulai dari tanah yang subur, gunung berapi yang menyediakan abu vulkanik, iklim tropis yang selalu disinari matahari sepanjang tahun, sumber air bersih yang melimpah, serta keberagaman tradisi dan budaya, termasuk di dalamnya adalah Budaya Pertanian.

Semenjak zaman kolonialisme Barat, Nusantara telah dikenal sebagai 'tanah surga dari Timur' oleh karena kesuburannya dan hasil pertanian yang mendunia terutama rempah-rempah dan hortikultura. Seiring berjalannya waktu, perkembangan pertanian juga tidak dapat dipungkiri. Aneka teknologi dan kreasi budidaya pertanian telah merebak. Penggunaan alat mesin pertanian canggih sudah menjadi trend di masa Pertanian Modern sekarang ini.

Bagi negara maju dalam kualitas sumber daya manusia dan kaya secara finansial, ini menjadi hal mudah dikarenakan mereka mempunyai modal kuat untuk mencapai Pertanian Modern dalam waktu singkat. Namun, untuk negara yang masih berkembang seperti di Indonesia, sangat membutuhkan banyak sekali dorongan dari berbagai pihak, baik pemerintah maupun swasta untuk menyediakan infrastruktur pertanian yang memadai, ilmu pertanian yang berbasis teknologi dan produksi berkelanjutan, serta suntikan dana untuk pengembangan pertanian dan pelatihan para petani khususnya di desa. Petani yang dikatakan berdaya adalah petani yang memiliki kekuatan atau kemampuan dalam: 1) memenuhi kebutuhan dasar sehingga memiliki kebebasan dalam mengungkapkan pendapat, bebas dari kelaparan, bebas dari kebodohan dan bebas dari kesakitan, 2) menjangkau sumbersumber produktif yang memungkinkan petani meningkatkan pendapatannya, dan memperoleh barang dan jasa yang mereka butuhkan, dan 3) berpartisipasi dalam proses pembangunan (Mutmainah dan Sumardjo, 2014).

Sinergi antara pemerintah dan swasta ini diharapkan dapat membawa petani Indonesia terpandang di mata dunia, serta produk-produk pertanian Indonesia dapat bersaing di mancanegara sekaligus untuk menekan jumlah impor bahanbahan pertanian yang saat ini dinilai hanya sebagai kepentingan politik semata, bukan untuk menguntungkan petani. Kedua pihak ini harus berani berkorban dan tekun dalam hal pemberdayaan petani baik secara fisik seperti infrastruktur penunjang, alat mesin pertanian, teknologi pertanian maupun keterampilan humaniora seperti pendidikan dan pelatihan bagi petani, dan lain-lain.

Tujuan tersebut hanya dapat diraih apabila petani desa diberdayakan sedemikian rupa agar dapat bersaing dengan secara nasional maupun internasional. Pemberdayaan tani dapat dilakukan oleh pihak pemerintah dan pihak swasta. Program dan kompetensi yang diberdayakan kepada petani haruslah berprinsip pada kompetensi lapangan dan aplikatif sehingga dapat diterapkan dalam kehidupan pertanian dan meningkatkan kualitas petani desa melalui teknologi 
pertanian, agar petani desa di Indonesia menjadi terpandang mata di dunia dan hasil pertanian Indonesia menjadi primadona seluruh dunia.

Berdasarkan Undang-Undang Republik Indonesia Nomor 19 Tahun 2013 tentang Perlindungan dan Pemberdayaan Petani Pasal 1 Ayat 2, Pemberdayaan Petani adalah segala upaya untuk meningkatkan kemampuan Petani untuk melaksanakan Usaha Tani yang lebih baik melalui pendidikan dan pelatihan, penyuluhan dan pendampingan, pengembangan sistem dan sarana pemasaran hasil Pertanian, konsolidasi dan jaminan luasan lahan pertanian, kemudahan akses ilmu pengetahuan, teknologi dan informasi, serta penguatan Kelembagaan Petani."

Pada Bab V, Pasal 40, disebutkan bahwa pemberdayaan petani dilakukan untuk memajukan dan mengembangkan pola pikir dan pola kerja Petani, meningkatkan Usaha Tani, serta menumbuhkan dan menguatkan Kelembagaan Petani agar mampu mandiri dan berdaya saing tinggi.

Pemberdayaan masyarakat memiliki tiga nilai utama, yakni 1) menciptakan suasana yang memungkinkan masyarakat untuk mengembangkan potensi yang dimiliki. Masyarakat harus bisa berdaya dan mandiri dengan potensi yang dimiliki, 2) memperkuat potensi dan daya saing masyarakat melalui langkah konkrit, menampung berbagai masukan dan menyediakan sarana prasarana fisik maupun sosial bagi masyarakat lapisan paling bawah, dan 3) melindungi dan membela kepentingan masyarakat lemah dengan artian agar masyarakat yang lemah dapat menjadi kuat serta berdaya saing dengan masyarakat yang lebih maju berbekal kearifan lokal masyarakat (Wijaya, 2010). Ini dilakukan terutama melalui penyadaran kritis (critical conscientization), pengorganisasian masyarakat (community organizing), dan penghantaran sumberdaya (resources delivery) (Irmayani et al, 2015; Salman, 2002).

Penelitian ini bertujuan untuk: 1) Mengetahui peranan swasta dalam pemberdayaan petani desa menuju pembangunan pertanian pedesaan terpadu, 2) Mengetahui tanggapan petani desa terhadap peran masing-masing pihak dalam pemberdayaan petani desa menuju pembangunan pertanian pedesaan terpadu, 3) Mengetahui peranan Sentra Pemberdayaan Tani dalam usaha menuju pembangunan pertanian pedesaan terpadu, dan 4) Mengetahui perbandingan kondisi sosial dan ekonomi masyarakat petani desa pada saat sebelum dan sesudah dilakukan pemberdayaan tani oleh pihak swasta.

\section{Metode Penelitian}

Penelitian akan dilaksanakan di SPT 11 Desa Nglanggeran, Kecamatan Patuk, Kabupaten Gunungkidul. Desa ini menjadi sasaran dari Yayasan Obor Tani sebagai salah satu Sentra Pemberdayaan Tani di Daerah Istimewa Yogyakarta. Penelitian akan dilaksanakan pada bulan Desember 2019 hingga bulan Februari 2020.

Desa Nglanggeran dipilih karena memiliki berbagai permasalahan alam, sosial ekonomi masyarakat yang diakibatkan oleh lokasi Desa Nglanggeran yang terletak di titik tertinggi Daerah Istimewa Yogyakarta, serta karena Desa Nglanggeran memiliki kesulitan dalam hal fasilitas penunjang pertanian salah satunya adalah ketersediaan air. Dengan faktor-faktor hambatan tersebut, peneliti dapat membandingkan antara kondisi sosial ekonomi sebelum dan sesudah dilaksanakan pemberdayaan tani yang diberikan oleh Yayasan Obor Tani dan 
Pemerintah Daerah kepada masyarakat petani Desa Nglanggeran, Kecamatan Patuk, Kabupaten Gunungkidul, Daerah Istimewa Yogyakarta.

Jenis data yang digunakan dalam penelitian kualitatif adalah kata-kata dan tindakan, dokumen, foto, rekaman suara, film dan statistik. Pengumpulan data dilakukan dengan cara Wawancara dan Observasi.

Alat Penelitian yang digunakan adalah alat tulis, buku, kamera, drone dan perekam suara. Alat-alat tersebut digunakan sebagai pencatatan data, baik secara tertulis, lisan dan kondisi sebenarnya untuk memberikan gambaran secara langsung.

Analisis data dilakukan dengan cara komparatif. Metode komparatif BeforeAfter dilakukan dengan membandingkan dua objek yang memiliki persamaan dan perbedaan. Dalam penelitian ini objek yang dibandingkan adalah kondisi masyarakat pertanian di Desa Nglanggeran. Hal-hal yang dibandingkan antara lain:

a. Kemampuan dan keterampilan budidaya masyarakat sebelum dan sesudah dilakukan pemberdayaan oleh pihak swasta.

b. Kondisi Desa Nglanggeran secara sosial, budaya dan ekonomi pertanian sebelum dan sesudah dilakukan pemberdayaan oleh pihak swasta.

\section{Hasil dan Pembahasan}

\section{Pemberdayaan Yayasan Obor Tani dan Desa Nglanggeran}

Yayasan Obor Tani didirikan pada tanggal 17 Januari 2006 oleh tokoh-tokoh aktivis sosial, pengusaha, akademisi, dan birokrasi. Yayasan Obor Tani terdiri dari pembina, pengurus, dan pengawas yang tersusun dari tokoh-tokoh mapan ekonomi. Yayasan ini bergerak pada bidang peningkatan kesejahteraan petani melalui berbagai program, salah satunya adalah program Sentra Pemberdayaan Tani. Sebagai subyek program, Yayasan Obor Tani memilih daerah pertanian termiskin untuk diberdayakan secara inovasi spesifik lokal dan adaptif, sehingga mudah untuk diadopsi dan dikembangkan oleh masyarakat.

Yayasan Obor Tani terlahir karena Bapak Budi Dharmawan melakukan ujicoba dalam menanam berbagai jenis buah di kebun milik pribadinya, dan menghasilkan produk yang dapat bersaing dengan produk impor. Kegemilangan ini diapresiasi oleh para rekan beliau untuk kemudian ilmu yang telah Bapak Budi Dharmawan dapatkan harus dibagikan kepada masyarakat desa. Hasil produksi yang berkualitas tersebut, diperoleh karena Indonesia memiliki berbagai komponen yang mendukung dunia pertanian, namun oleh karena tidak dipergunakan dengan baik sehingga produk dalam negeri Indonesia kalah dengan produk impor baik dari segi kuantitas maupun kualitas. Akhirnya pada tanggal 17 Januari 2006, Bapak Budi Dharmawan mendirikan Yayasan Obor Tani yang memiliki fokus untuk pemberdayaan petani desa terkhusus pada produk hortikultura buah dan sayur.

Pemberdayaan petani desa ini terutama sekali kepada daerah yang tidak mempunyai sumber air dan kondisi tanah yang kering. Daerah-daerah tersebut disebut sebagai Potret Desa Miskin dan Tanah Terlantar (PDMTT). PDMTT ini mempunyai beberapa klasifikasi, yakni: 1) infrastruktur pertanian yang belum memadai, 2) belum memiliki akses pengetahuan dan informasi tentang jenis tanaman unggul, 3) sentra pendidikan dan pelatihan yang belum tersedia, 4) tidak optimalnya penyuluhan dan pembinaan, 5) tidak mempunyai akses untuk mendapatkan bibit, sarana produksi tanaman dan produksi yang baik. 
Visi Yayasan Obor Tani adalah meningkatkan kesejahteraan petani, khususnya petani buah. Misinya, membangun SPT di desa-desa, untuk mendidik dan memberdayakan petani di desa dengan budidaya tanaman buah yang memiliki nilai ekonomi tinggi sesuai dengan standar, sehingga dapat menghasilkan buah yang bermutu tinggi. Dengan demikian pendapatan lebih yang juga tinggi. Kesejahteraan menjadi meningkat. Visi dan Misi Yayasan Obor Tani ini sesuai dengan apa yang tertera dalam UU RI No. 19 Tahun 2013 tentang Perlindungan dan Pemberdayaan Petani, pada Bab 5 Pasal 40 disebutkan bahwa pemberdayaan petani dilakukan untuk memajukan dan mengembangkan pola pikir dan pola kerja Petani, meningkatkan Usaha Tani, serta menumbuhkan dan menguatkan Kelembagaan Petani agar mampu mandiri dan berdaya saing tinggi.

Pendirian 5 SPT awal merupakan bentuk kinerja antara pemerintah, swasta dan Yayasan Obor Tani. Hal ini sesuai dengan teori dari Wulanjari dan Setiani, (tanpa tahun) yang mengatakan bahwa dalam pelaksanaan kegiatan pemberdayaan masyarakat tidak hanya dilakukan oleh institusi pemerintah, melainkan juga dapat dilakukan oleh kelompok masyarakat itu sendiri, peran lembaga swasta, lembaga pendidikan serta stakeholders lainnya. Sinergi berbagai pihak dalam pelaksanaan pemberdayaan petani juga diperkuat dalam UU RI No. 19 Tahun 2013, Pemerintah Pusat dan Daerah dapat bersinergi dengan badan dan/atau lembaga terakreditasi untuk melaksanakan pendidikan dan pelatihan; penyuluhan dan pendampingan; pengembangan sistem dan sarana pemasaran hasil Pertanian; konsolidasi jaminan luasan lahan pertanian; kemudahan akses ilmu pengetahuan, teknologi dan informasi; serta penguatan Kelembagaan Petani untuk menuju Pertanian Indonesia yang berdaya saing internasional.

Yayasan Obor Tani telah membangun 80 Sentra Pemberdayaan Petani (SPT) yang tersebar mulai dari Pulau Sumatera, Jawa, Kalimantan hingga Nusa Tenggara. Berdasarkan data Yayasan Obor Tani, dari total 80 SPT, sejumlah 26 SPT merupakan berdayaan 100\% oleh Yayasan Obor Tani, 6 SPT sedang dalam proses pembuatan, 6 SPT merupakan swadaya masyarakat, dan 42 SPT hanya menerima bantuan berupa pembuatan embung oleh Yayasan Obor Tani. Untuk total 48 SPT yang tidak diberdayakan $100 \%$ oleh Yayasan Obor Tani, peran yayasan dalam pemberdayaan petani di SPT-SPT tersebut adalah memberikan bantuan dalam hal sarana produksi dalam jumlah terbatas serta Ilmu Budidaya yang tetap dicurahkan sepenuhnya.

Pada tanggal 15 Agustus 2009, dalam statuta SPT yang disusun dan disahkan oleh Yayasan Obor Tani, telah ditetapkan bahwa Yayasan Obor Tani bekerjasama dengan Gapoktan Kumpul Makaryo yang berkedudukan di Nglanggeran Kulon, RT 14 RW 03, Desa Nglanggeran, Kecamatan Patuk, Kabupaten Gunung Kidul, Provinsi Daerah Istimewa Yogyakarta. Gapoktan Kumpul Makaryo adalah pihak yang memiliki dan menguasai dana untuk pembangunan SPT yang berasal dari Bantuan Keuangan Gubernur DIY yang disalurkan melalui Pemerintah Kabupaten Gunungkidul. Gapoktan tidak diwajibkan untuk mengembalikan bantuan yang diterima dalam bentuk apapun juga, sedangkan Yayasan Obor Tani adalah pihak yang akan melaksanakan pembangunan Sentra Pemberdayaan Tani.

Pada SPT Nglanggeran ini, lokasi yang disediakan adalah seluas 20 hektar untuk lahan penanaman 3.100 pohon durian menoreh kuning dan kelengkeng itoh. Ketentuan peserta program SPT adalah: 1) jumlah peserta kurang lebih $100 \mathrm{KK}$ yang diseleksi dan ditetapkan sebagai Petani Inti (NITI); 2) letak lahan peserta program 
SPT adalah maksimal 1 KM dari lokasi waduk mini; 3) luas lahan untuk tiap peserta program SPT maksimum seluas $2.000 \mathrm{~m}^{2}$. Infrastruktur SPT yang diberikan berupa:

1) Waduk mini dengan kapasitas daya tampung air hujan sebesar $7.200 \mathrm{~m}^{3}$ untuk pengairan lahan seluas $2.304 \mathrm{~m}^{2}$.

2) Air waduk akan digunakan untuk menyiram 3.100 tanaman Durian Menoreh Kuning dan Kelengkeng Itoh selama 5 bulan musim kemarau pada setiap tahun.

3) Wisma SPT berwujud bangunan permanen seluas $100 \mathrm{~m}^{2}$ di atas lahan seluas $2.000 \mathrm{~m}^{2}$ dan terletak di satu areal dengan letak Waduk mini. Wisma SPT ini sedianya akan digunakan untuk gudang saprotan, tempat pertemuan, kantor SPT, tempat tinggal manajer dan wakil manajer SPT, serta untuk menampung bibit tanaman, serta lahan untuk riset dan percobaan.

Berdasarkan surat perjanjian, kerjasama yang dilakukan oleh Yayasan Obor Tani dan Gapoktan Kumpul Makaryo berakhir pada tanggal 31 Desember 2015 saat proyek diserahkan dari Yayasan Obor Tani kepada Gapoktan untuk selanjutnya dilakukan pengembangan secara swadaya oleh Gapoktan.

\section{Faktor-Faktor Pendukung Keberhasilan Proses Pemberdayaan Petani Desa}

Pemberdayaan petani desa dapat berhasil apabila sinergi antara pemberdaya dan petani yang diberdayakan dapat terjadi. Sebelum menjadi petani berdayaan Yayasan Obor Tani, petani desa Nglanggeran menjadi petani binaan dari pemerintah. Terdapat beberapa faktor yang mempengaruhi keberhasilan pemberdayaan petani di Desa, yakni: 1) Kualitas fasilitas pemberdayaan/KFP, 2) Intensitas Pemberian Fasilitas Pemberdayaan Petani Desa/IP-FPPD, 3) Kualitas Pembimbing Pemberdayaan Petani Desa/KP3D.

\section{Kualitas Fasilitas Pemberdayaan/KFP.}

Dalam melaksanakan pemberdayaan petani desa, digunakan berbagai fasilitas baik berujud fisik maupun non-fisik. Kualitas dari fasilitas-fasilitas tersebut akan mempengaruhi dan berdampak pada hasil produksi petani desa. Pada saat menjadi petani binaan pemerintah Daerah Istimewa Yogyakarta di bawah asuhan Dinas Pertanian, petani mendapat fasilitas pemberdayaan secara fisik berupa benih, pupuk, alat pertanian dan beberapa yang memiliki ternak mendapat bantuan kandang dan hewan untuk kemudian dibudidayakan.

Menurut petani, pemerintah dalam melaksanakan pemberdayaan hanya memberikan bantuan fisik berupa bibit, pupuk, pelatihan-pelatihan mengenai masalah teknis budidaya, pemberdayaan kelompok tani dan pengendalian hama, dan beberapa petani mendapatkan bantuan hewan ternak dan kandang. Bentukbentuk fasilitas pemberdayaan yang diberikan hanyalah sebagian kecil dari keseluruhan fasilitas pemberdayaan yang diatur dalam UU RI No. 19 Tahun 2019 Bab ke-10, Bagian ke-2 mengenai prasarana pertanian dan sarana produksi pertanian. Prasarana yang dimaksud adalah jalan usaha tani, jalan produksi dan jalan desa, bendungan, dam, jaringan irigasi, embung, jaringan listrik, pergudangan, pelabuhan dan pasar. Sedangkan yang dimaksud dengan sarana produksi pertanian adalah benih, bibit, bakalan ternak, pupuk, pestisida, pakan dan obat hewan yang sesuai dengan standar mutu, termasuk di dalamnya adalah alat dan mesin pertanian 
yang sesuai dengan kondisi lokal masyarakat. Materi pemberdayaan petani berupa pelatihan diatur dalam UU RI No. 19 Tahun 2013 Bab 5, Bagian ke-2, Pasal 42 Ayat 2 pendidikan dan pelatihan pemberdayaan petani meliputi pengembangan program pelatihan dan pemagangan, pemberian beasiswa bagi Petani untuk mendapatkan pendidikan di bidang Pertanian, atau pengembangan pelatihan kewirausahaan di bidang agribisnis.

Jika dibandingkan dengan fasilitas pemberdayaan petani dari pemerintah, Yayasan Obor Tani juga memberikan tambahan-tambahan fasilitas yang digunakan untuk pemberdayaan petani secara total. Fasilitas yang diberikan meliputi waduk mini, pembimbingan oleh kader Yayasan Obor Tani yang tinggal di lokasi selama kontrak kerja, bibit unggul, pupuk, saluran pengairan, pelatihan 11 konsep budidaya, wisma tani sebagai tempat berkumpul para petani binaan. Selain infrastruktur fisik, pembimbingan diberikan dalam bentuk pendidikan dan pelatihan. Materi pendidikan dan pelatihan mengenai: 1) Persiapan lahan dan pembersihan; 2) Pembibitan; 3) Penyiraman; 4) Pemupukan; 5) Pengendalian Hama dan Penyakit (PHP) Preventif dan pemeliharaan rutin; 6) Bu-Bu (Bunga dan Buah); 7) Panen; 8) Pasca Panen: cleaning, grading, labelling, packaging; 9) PHP Kuratif; 10) Pengorganisasian Perkebunan Buah dan 11) Pemasaran dan Agrowisata Budidaya. Fasilitas pemberdayaan petani desa yang diberikan merupakan hasil riset dan berkualitas karena didatangkan langsung dari Thailand serta Malaysia walaupun sudah ada perubahan-perubahan yang disesuaikan dengan kondisi agroklimatologi dan sosial budaya masyarakat di Indonesia.

Berdasarkan pernyataan dari petani narasumber, Desa Nglanggeran sempat mendapat cap merah dalam penerima bantuan pemerintah. Spekulasi yang muncul di kalangan masyarakat adalah terjadinya tindak korupsi bantuan pemberdayaan petani. Sedangkan dalam Yayasan Obor Tani, para pembina Yayasan selalu menjamin agar bantuan yang diberikan tidak terjadi tindak korupsi karena dapat menyebabkan pemberdayaan petani desa tidak berjalan dengan baik, selain itu juga mengakibatkan terjadinya tindak pidana yang merugikan berbagai pihak terutama petani sebagai subyek pemberdayaan masyarakat.

Sebagian besar masyarakat petani Desa Nglanggeran yang menjadi binaan pemerintah hanya merasakan perubahan sedikit saja, mereka bercocok tanam hanya untuk membeli kebutuhan pupuk di musim tanam ke-2 setiap tahunnya. Mereka tidak mendapatkan untung karena hasil produksi sawah dan ladang para petani Desa Nglanggeran hanya digunakan untuk konsumsi pribadi, apabila dijual tidak menutup untuk kebutuhan lain, hanya bersifat meringankan saja.

Selama menjadi petani binaan pemerintah, para petani Desa Nglanggeran menyelesaikan permasalahan dengan inisiatif sendiri dan tidak ada anjuran dari petugas pemberdaya dari pihak pemerintah. Masyarakat secara swadaya membangun sumur bor pribadi dan membeli air dari luar kabupaten bagi yang mampu, serta kendala apabila memiliki ternak harus mencari rumput sebagai pakan hewan hingga ke daerah Kabupaten Klaten, Provinsi Jawa Tengah. Hal ini menunjukkan bahwa pemberdayaan petani yang diberikan oleh pemerintah kepada petani Desa Nglanggeran belum bisa menyelesaikan permasalahan mendasar. Namun, setelah Yayasan Obor Tani menjadikan Desa Nglanggeran sebagai salah satu SPT berdayaan, perubahan signifikan terjadi terutama mengenai penyelesaian permasalahan utama di Desa Nglanggeran. Di musim kemarau, petani berdayaan 
dapat melakukan kegiatan budidaya dengan nyaman karena mereka sudah memiliki embung yang menjadi wadah penyimpanan air hujan. Selain itu, berkat hasil penjualan produk mereka dapat membuat secara swadaya embung-embung mini di masing-masing wilayah produksi. Hal ini sesuai dengan teori yang dikemukakan oleh Wijaya (2010) mengenai peran utama pemberdayaan masyarakat adalah dapat menyelesaikan permasalahan serta membawa masyarakat dapat berdaya dan mandiri dalam membangun kehidupan yang layak menggunakan potensi lokal masyarakat.

Sejak awal Yayasan Obor Tani terjun ke Desa Nglanggeran, para petani sudah tertarik dan memprediksi adanya perkembangan kehidupan dan menyelesaikan permasalahan alam Desa Nglanggeran. Berdasarkan pernyataan dari petani narasumber di atas, Yayasan Obor Tani telah melaksanakan tahap pertama pemberdayaan masyarakat sesuai dengan teori dari Sulistiyani (2004) yang mengatakan bahwa dalam tahap pertama, pemberdaya menciptakan kondisi yang dapat menjamin efektivitas keberlangsungan proses pemberdayaan. Pemberdaya memberikan sentuhan kesadaran mengenai penumbuhan keinginan dan kesadaran masyarakat tentang kondisi saat itu, sehingga dapat merangsang kesadaran masyarakat mengenai perlunya memperbaiki kondisi untuk memperoleh masa depan yang lebih baik. Setelah masyarakat tersentuh, pemberdaya memancing semangat kebangkitan masyarakat untuk meningkatkan kemampuan diri dan lingkungan. Dengan semangat inilah diharapkan dapat membawa masyarakat untuk sampai pada kesadaran dan kemauan untuk belajar. Dengan belajar, masyarakat dapat semakin terbuka dan merasa membutuhkan pengetahuan dan keterampilan untuk semakin memperbaiki kondisi yang ada. Yayasan Obor Tani merangsang agar masyarakat Desa Nglanggeran mau untuk diberdayakan sehingga dapat memperbaiki taraf hidup mereka.

Setelah menjadi petani binaan Yayasan Obor Tani, petani Desa Nglanggeran mengalami peningkatan yang sangat pesat. Walaupun tidak dapat dibandingkan secara langsung karena berbeda komoditas, namun dapat dibandingkan bahwa Yayasan Obor Tani dapat menyelesaikan permasalahan mendasar yang terjadi sejak dahulu yakni masyarakat Desa Nglanggeran memiliki cadangan air di musim kemarau. Selain itu, Yayasan Obor Tani dapat merubah gaya pertanian utun yang hanya untuk konsumsi pribadi dan hanya menjual sebagian pada saat membeli kebutuhan input pertanian di musim kedua, menjadi gaya pertanian modern yang dapat berkembang tidak hanya untuk menjadi konsumsi pribadi, namun juga dapat memproduksi dan memasarkan sehingga mendapatkan keuntungan yang jauh lebih tinggi daripada semasa hanya menanam palawija dan sebagainya.

Yayasan Obor Tani juga ingin membuka mata berbagai pihak khususnya pemerintah untuk tergelitik dan meniru apa yang telah diperbuat Yayasan Obor Tani dengan mendirikan berbagai Sentra Pemberdayaan Rakyat dengan fokus masingmasing pada kearifan lokal sehingga dengan demikian dapat membawa Bangsa Indonesia berdaya, mandiri dan berdaya saing secara internasional.

Dalam pandangan Yayasan Obor Tani, Indonesia harus berfokus pada pembangunan dan pemberdayaan Bangsa, yang artinya adalah pemberdayaan sumber daya manusia. Pemberdayaan harus meliputi pada perubahan mental manusia Indonesia yang semula terpuruk harus dididik dan diseleksi seperti halnya seleksi tentara. Manusia Indonesia harus memiliki bekal kejujuran dan kepintaran. 
Yayasan Obor Tani menterjemahkan kepintaran adalah suatu cara untuk menciptakan produk yang berkualitas baik secara kuantitas maupun mutu produk. Berbekal kepintaran dan kejujuran ini, pemerintah, pengusaha dan lembaga lainnya harus bersinergi dalam mewujudkan pemberdayaan masyarakat berbasis kearifan lokal, sebagai contoh adalah masyarakat ukir Jepara. Masyarakat harus dibina dan dididik supaya dapat meningkatkan produktivitasnya dengan berbagai cara, melalui pelatihan yang rutin dan terus menerus, pemberian fasilitas yang berkualitas, pembimbingan dalam memproduksi barang berkualitas, maupun teknologi inovasi yang dapat mempermudah masyarakat produsen. Dengan demikian, produk yang dihasilkan masyarakat di dalam negeri dapat bersaing dengan produk impor, dan imbasnya kepada peningkatan ekonomi nasional, peningkatan taraf hidup dan kesejahteraan masyarakat lapisan bawah, penurunan jumlah impor dan meningkatkan jumlah ekspor. Hal ini sesuai dengan teori yang dikemukakan oleh Dekasari (2016) bahwa dengan ketersediaan fasilitas program pemberdayaan petani, masyarakat dapat mengalami peningkatan tidak hanya dalam segi sosial ekonomi saja, melainkan juga pribadi petani tersebut. Berbekal hal ini, Indonesia dapat menjadi negara yang terpandang di mata dunia berbekal Trisakti Bung Karno, yaitu Berdikari dalam Ekonomi, Berkedaulatan dalam Politik, dan Berkepribadian dalam Kebudayaan. Hal ini sesuai dengan yang tertera dalam UU RI No. 19 Tahun 2013 yang menyebutkan bahwa pelaksanaan pemberdayaan petani memiliki tujuan yaitu Pertanian Indonesia yang berdaya saing internasional. Masyarakat Desa Nglanggeran telah melalui 3 tahap pelaksanaan pemberdayaan masyarakat yang dikemukakan oleh Sulistiyani (2004) yaitu: 1) tahap penyadaran yaitu di mana Yayasan Obor Tani memberikan penjelasan di awal perjumpaan dengan petani Desa Nglanggeran, 2) tahap tranformasi kemampuan yakni pada saat terjadi pemberdayaan, dan 3) tahap peningkatan kemampuan fisik dan non-fisik, yang dibuktikan melalui praktik kerja.

\section{Intensitas Pemberian Fasilitas Pemberdayaan Petani Desa / IP-FPPD.}

Menurut Edwards III (2007), terdapat empat faktor pendukung keberhasilan program pemberdayaan masyarakat, yakni 1) komunikasi yang lancar dan terpercaya dapat meyakinkan subyek menerima pemberdayaan dengan baik, 2) ketersediaan sumber daya yang dibutuhkan masyarakat, 3) disposisi pelaku pemberdaya yang sungguh-sungguh mau memberdayakan masyarakat dan 4) struktur birokrasi yang tidak berbelit. Ketersediaan sumber daya baik fisik maupun non-fisik memiliki peranan yang vital, tidak terkecuali adalah pemberdayaan petani desa.

Pemberdayaan petani Desa Nglanggeran juga dipengaruhi oleh ketersediaan sumberdaya tersebut. Fasilitas pemberdayaan petani desa oleh pemerintah diberikan setahun sekali, namun dalam pelaksanaannya sering terlambat sehingga jadwal budidaya terganggu. Berbeda dengan Yayasan Obor Tani yang memberikan pendampingan selama 3,5 tahun penuh. Bantuan diberikan langsung kepada petani setiap musim sesuai kebutuhan dan ketersediaan di gudang, serta pembimbing SPT yang menginap selama 3,5 tahun di Wisma Tani yang dibangun oleh Yayasan Obor Tani. Dengan kondisi ini, petani mendapatkan pembimbingan dan pengawasan setiap hari oleh pembimbing SPT sehingga permasalahan yang muncul dapat diselesaikan pada saat itu juga.

Fasilitas pemberdayaan oleh pemerintah hanya cukup untuk 1 musim tanam, sedangkan di Desa Nglanggeran terjadi 2x musim tanam padi. Petani Desa 
Nglanggeran masa itu bercocok tanam hanya untuk konsumsi pribadi, dan menjual sebagian hanya untuk membeli kebutuhan input produksi walaupun tidak setiap panen mereka menjual produk mereka. Hal ini berbeda dengan Yayasan Obor Tani yang memberikan fasilitas pemberdayaan tani dengan kalkulasi yang lengkap di awal sehingga mencukupi untuk 3,5 tahun pemberdayaan untuk memastikan agar petani tidak kekurangan sumber daya.

Petani Desa Nglanggeran mengalami peningkatan penghasilan sekitar Rp. 45.000.000,- dengan demikian petani berdayaan Yayasan Obor Tani telah mengalami keuntungan sebesar Rp. 30.000.000,- jika dihitung dengan biaya produksi Rp. 15.000.000,- selama 3,5 tahun. Hal ini menunjukkan bahwa ketersediaan sumber daya/intensitas pemberian fasilitas pemberdayaan petani desa menjadi salah satu faktor pendukung kelancaran proses pemberdayaan petani desa. Sifat pemberdayaan petani desa oleh Yayasan Obor Tani bersifat one-way-traffic yang berarti petani tidak berkewajiban untuk mengembalikan modal utama yang dipinjamkan di awal oleh Yayasan Obor Tani.

\section{Kualitas Pembimbing Pemberdayaan Petani Desa/KP3D.}

Kualitas fasilitator menjadi salah satu faktor terpenting lainnya dalam pelaksanaan pemberdayaan masyarakat. Menurut Daniels (2007) fasilitator adalah petugas yang bernaung di dalam sebuah institusi baik swasta maupun pemerintah, yang memiliki pengetahuan, keterampilan, sikap untuk mengelola program-program yang berbasis masyarakat. Fungsi fasilitator adalah sebagai jembatan antara institusi dan masyarakat berdayaan untuk memfasilitasi atau pendampingan yang bertujuan untuk menyertakan masyarakat dalam menemukan potensi diri, memberi tambahan nilai untuk masyarakat sehingga terjadi peningkatan taraf kehidupan. Dalam Yayasan Obor Tani, fasilitator ini disebut sebagai kader tani.

Yayasan Obor Tani memastikan agar kader tani dapat menyampaikan pemberdayaan dengan sebaik-baiknya dengan kepribadian utama yaitu pintar atau menguasai materi pemberdayaan dan jujur. Dengan bekal kedua hal ini, Yayasan Obor Tani percaya pemberdayaan petani desa dapat berjalan dengan baik. Seleksi kader tani dilakukan secara ketat seperti seleksi tentara. Namun, Yayasan Obor Tani memiliki kekurangan karena tidak mempersiapkan suatu lembaga yang digunakan untuk melatih kader tani. Seleksi kader tani dilakukan secara pribadi di perusahaan milik Bapak Budi Dharmawan, barulah di tahun 2014 lalu didirikan Yayasan Ilmu Tani untuk mengatasi kekurangan Yayasan Obor Tani tersebut agar kader tani yang dikirim ke desa sebagai fasilitator pemberdayaan tani dapat semakin terjamin kualitas serta kuantitasnya. Dalam hal ini Yayasan Obor Tani bergerak sesuai dengan teori yang dikemukakan oleh Daniels (2007) yang mengungkapkan bahwa fasilitator haruslah pribadi yang berkualitas dan terjamin penguasaan materinya.

Dalam perjalanannya, kader tani yang dikirim ke desa ternyata mengalami berbagai kendala. Kendala bahasa, budaya dan agama selama pemberdayaan petani desa oleh Yayasan Obor Tani menuntut agar seleksi kader tani dilakukan semakin ketat. Dengan Yayasan Ilmu Tani, Yayasan Obor Tani berkomitmen untuk mendidik dan melatih kader tani dari desa lokal untuk kemudian dikembalikan ke desa masing-masing untuk menjadi kader tani/fasilitator pemberdayaan petani. Dengan hal ini, kendala-kendala yang dialami sebelumnya dapat hilang dan menjadikan proses pemberdayaan tani semakin lancar. 
Dalam pelaksanaanya, masyarakat Desa Nglanggeran walaupun dua kali mendapat fasilitator dari suku Jawa, namun juga tidak sesuai karena kemampuan pribadi dan keterbatasan fisik fasilitator tersebut. Pada tahun ke-3, mereka mendapat fasilitator anak muda dari Suku Batak, namun dapat berjalan dengan baik walaupun fasilitator muda tersebut tidak menguasai Bahasa Jawa. Dapat diketahui bahwa selain kepintaran, kejujuran dan kemampuan memfasilitasi yang dimiliki oleh fasilitator, kondisi internal masyarakat juga mempengaruhi kelancaran proses pemberdayaan tani. Hal ini sesuai dengan teori yang dikemukakan oleh Rohmatin (2016) dan (Laily, Ribawanto dan Nurani, t.thn.) bahwa kondisi sosial budaya intern masyarakat dapat menjadi faktor penghambat atau pendorong kelancaran pemberdayaan masyarakat. 
Tabel 1

Perbandingan Fasilitas Pemberdayaan Petani Desa oleh Pemerintah dan Yayasan Obor Tani.

\begin{tabular}{|c|c|c|c|c|}
\hline No & Aspek & Pemerintah & $\begin{array}{c}\text { Yayasan } \\
\text { Obor Tani }\end{array}$ & Kualitas \\
\hline 1. & $\begin{array}{l}\text { Bantuan } \\
\text { Fisik } \\
\text { (pupuk, } \\
\text { saprodi, } \\
\text { bibit, } \\
\text { dsb) }\end{array}$ & $\begin{array}{c}\text { Pupuk, } \\
\text { saprodi, } \\
\text { bibit, } \\
\text { kandang, } \\
\text { bibit hewan. }\end{array}$ & $\begin{array}{l}\text { Waduk } \\
\text { mini, wisma } \\
\text { tani, pupuk, } \\
\text { saprodi, } \\
\text { bibit. }\end{array}$ & $\begin{array}{l}\text { Pemerintah : } 1 \text { tahun } 1 \times \text { untuk } 1 \\
\text { masa tanam, spesifikasi standar } \\
\text { rendah, dan tidak menyelesaikan } \\
\text { permasalahan alami Nglanggeran, } \\
\text { sering terlambat dan pernah terjadi } \\
\text { tindak korupsi. } \\
\text { Yayasan Obor Tani : Setiap tahun, } \\
\text { untuk setiap masa tanam selama 3,5 } \\
\text { tahun secara rutin. Kualitas } \\
\text { internasional yang sudah teruji dan } \\
\text { berhasil menyelesaikan } \\
\text { permasalahan alami Nglanggeran, } \\
\text { selalu tepat waktu dan tidak ada } \\
\text { korupsi. }\end{array}$ \\
\hline 2. & $\begin{array}{l}\text { Bantuan } \\
\text { non } \\
\text { Fisik }\end{array}$ & Pelatihan & $\begin{array}{c}\text { Pelatihan, } \\
\text { Pembimbin } \\
\text { gan, } \\
\text { Fasilitasi } \\
\text { Penjualan } \\
\text { dalam } \\
\text { bentuk } \\
\text { Koperasi } \\
\text { Swadaya } \\
\text { dan } \\
\text { Pendidikan } \\
\text { melalui } \\
\text { Yayasan } \\
\text { Ilmu Tani }\end{array}$ & $\begin{array}{l}\text { Pemerintah : } \\
1 \text { tahun } 1 x \text { di bulan Juli atau } \\
\text { Agustus, dan hanya diberikan } \\
\text { pendidikan dasar. } \\
\text { Yayasan Obor Tani : } \\
\text { Kader pelatih/ pembimbing } \\
\text { ditempatkan selama 3,5 tahun dan } \\
\text { menginap di wisma tani untuk } \\
\text { setiap hari melakukan bimbingan } \\
\text { untuk } 11 \text { tahap budidaya. }\end{array}$ \\
\hline 3. & $\begin{array}{l}\text { Keuntu } \\
\text { ngan } \\
\text { usahata } \\
\text { ni }\end{array}$ & $\begin{array}{c}\text { Hanya } \\
\text { digunakan } \\
\text { untuk } \\
\text { konsumsi } \\
\text { pribadi }\end{array}$ & $\begin{array}{c}\text { Rp. } \\
\text { 15.000.000,- } \\
\text { hingga Rp. } \\
\text { 45.000.000,- } \\
\text { per bulan }\end{array}$ & $\begin{array}{l}\text { Perubahan terjadi signifikan dari } \\
\text { petani utun hingga petani } \\
\text { profesional. }\end{array}$ \\
\hline
\end{tabular}

Sumber: Data primer setelah diolah

\section{Kesimpulan}

Yayasan Obor Tani memberikan berbagai fasilitas pemberdayaan petani desa berupa dana CSR dari perusahaan swasta maupun BUMN, fasilitas fisik dan nonfisik yang telah dikalkulasi secara matang sebelum pendirian Sentra Pemberdayaan tani untuk durasi pemberdayaan selama 3,5 tahun berupa embung, wisma tani, pupuk, bibit, alat mesin pertanian dan kader tani, pelatihan-pelatihan, 
pembimbingan dan keterampilan. Semua fasilitas yang diberikan ini merupakan adopsi dari Thailand yang telah disesuaikan dengan kondisi sosial budaya dan alam Indonesia sehingga terjamin kualitas dan kuantitas yang dihasilkannya.

Petani Desa Nglanggeran merasa setelah diberdayakan oleh Yayasan Obor Tani setelah mengalami perubahan yang sangat pesat, dan meningkatkan taraf hidup masyarakat petani yang semula hanya petani utun. Perubahan ini dirasakan karena sewaktu masih menjadi petani berdayaan Pemerintah, mereka hanya bisa bertani untuk mencukupi kebutuhan pribadi dan tidak mengalami keuntungan finansial yang berarti, namun setelah diberdayakan oleh Yayasan Obor Tani mereka mempunyai penghasilan tetap hingga Rp. 45.000.000,- per tahun.

Berdasarkan pengalaman petani Desa Nglanggeran, pemberdayaan petani desa yang diberikan oleh pemerintah belum memberikan perubahan yang berarti dan tidak menyelesaikan permasalahan utama, sedangkan pemberdayaan petani desa yang diberikan oleh Yayasan Obor Tani mengubah secara keseluruhan kehidupan masyarakat petani sekaligus menyelesaikan berbagai permasalahan masyarakat seperti kondisi alam, sosial budaya dan ekonomi masyarakat.

\section{Daftar Pustaka}

Daniels, R., 2007. "Peran Fasilitator Pengembangan Masyarakat (Memahami Dengan Sesungguhnya Peranan Fasilitator Masyarakat/Profil Fasilitator)." Jurnal Reading Material Program Pengembangan Fasilitator Pemberdayaan Masyarakat.

Dekasari, D. A., 2016. "Pemberdayaan Petani dalam Meningkatkan Ketahanan Pangan di Desa Sambiroto, Kecamatan Padas, Kabupaten Ngawi." Jurnal Analisa Sosiologi 5 (1): 38-50.

Edwards III, G.C. 2007. Jurnal Administrasi Negara. Jakarta: LAN.

Irmayani, D. Salman, Amaluddin, S.R. Busaeri, 2015. Sustainability of Rice Farmers: Farming of Rural Communities in the Spiritual Meaning Perspective of Seed Storage, Journal of Social and Development Sciences, Vol.6, No. 4.

Laily, S. F. R, H. Ribawanto, F. Nurani. t.thn. "Pemberdayaan Petani dalam Meningkatkan Ketahanan Pangan (Studi di Desa Betet, Kecamatan Ngronggot, Kabupaten Nganjuk)." Jurnal Administrasi Publik 2 (1): 147-153.

Mutmainah, R., dan Sumardjo. 2014. "Peran Pemimpin Kelompok Tani dan Efektivitas Pemberdayaan Petani." Sodality: Jurnal Sosiologi Pedesaan.

Rohmatin, S. A., 2016. “Studi Eksploratif tentang Faktor-Faktor yang Mempengaruhi Pelaksanaan Program Pemberdayaan Ekonomi Kelompok Swadaya Masyarakat (KSM) di Kelurahan Sidotopo Kecamatan Semampir Kota Surabaya." Kebijakan dan Manajemen Publik 4 (3).

Salman, D., 2002. Apa dan Bagaimana Pemberdayaan Masyarakat. Makalah, PSKMP Unhas: Makassar. 
Sulistiyani, A. T. 2004. Kemitraan dan Model-Model Pemberdayaan. Yogyakarta: Gava Media.

Wijaya, M. 2010. “Kemiskinan dan Pemberdayaan Masyarakat Desa." Journal of Rural and Development 1 (1).

Wulanjari, M. E., dan Cahyati S., t.thn. "Strategi Pemberdayaan Petani dalam Berusahatani." Litbang BPTP Jawa Tengah 41-51. 